Article

\title{
Composting of Vegetable Waste Using Microbial Consortium and Biocontrol Efficacy of Streptomyces Sp. Al-Dhabi 30 Isolated from the Saudi Arabian Environment for Sustainable Agriculture
}

\author{
Naif Abdullah Al-Dhabi *, Galal Ali Esmail, Abdul-Kareem Mohammed Ghilan and \\ Mariadhas Valan Arasu \\ Addiriyah Chair for Environmental Studies, Department of Botany and Microbiology, College of Science, \\ King Saud University, P.O. Box 2455, Riyadh 11451, Saudi Arabia; gesmail@ksu.edu.sa (G.A.E.); \\ 436107839@student.ksu.edu.sa (A.-K.M.G.); mvalanarasu@ksu.edu.sa (M.V.A.) \\ * Correspondence: naldhabi@ksu.edu.sa; Tel./Fax: +966-11-4697204
}

Received: 18 October 2019; Accepted: 28 November 2019; Published: 2 December 2019

check for updates

\begin{abstract}
Thirty-seven root-associated Actinomycetes were isolated from the tomato plant for plant growth promoting activity. Among these, ten were selected for phosphate solubilisation, the production of siderophores, and indole acetic acid. Out of ten, eight Actinomycetes solubilised phosphate, whereas, Streptomyces sp. Al-Dhabi 30 showed better activity $(43.1 \mathrm{mg} / \mathrm{dL})$. Actinomycetes produced siderophore and the concentration ranged between 1.6 and $42.1 \mu \mathrm{g} / \mathrm{mL}$. Streptomyces sp. Al-Dhabi 30 showed the ability to produce a maximum amount of indole acetic acid (IAA) ( $43 \mu \mathrm{g} / \mathrm{mL})$, chitinase $(43.1 \mathrm{U} / \mathrm{mL})$, cellulase $(67 \mathrm{U} / \mathrm{mL})$, and protease $(121 \mathrm{U} / \mathrm{mL})$ than other strains. Further, vegetable waste was used as the bulk material for composting using Streptomyces sp. Al-Dhabi 30 along with microbial consortium. Total nitrogen content was 3.8\% in Streptomyces sp. Al-Dhabi 30 inoculated compost, whereas $2.7 \%$ organic nitrogen was detected in the control. In the compost vegetable waste, the C:N ratio was 10.07, whereas it was 17.51 in the control. The vegetable waste composted with Streptomyces sp. Al-Dhabi 30, Lactobacillus plantarum ATCC 33222, and Candidautilis ATCC 9950 showed antagonistic activity and the supplemented compost enhanced shoot, root height, and total weightin tomato plants. These findings clearly suggest the use of Streptomyces sp. Al-Dhabi 30 as a potential biocontrol agent.
\end{abstract}

Keywords: Streptomyces sp.; antagonistic activity; phytopathogens; tomato plant; growth promoters

\section{Introduction}

Biological waste is mainly found in municipal solid waste (MSW) and more than 75\% MSW composed of biodegradable substances. However, the amount of this biodegradable waste in MSW depends on the country from where MSW is generated. For the past three decades, there has been increased population, urbanization and accelerating economy, stimulating a steep increase in MSW. According to Zhou et al. [1], China produces 96 million tonnes of kitchen waste/year, whereas India generates about 68.8 million tonnes/year. Many methods have been proposed to dispose of MSW and waste dumping in a disposal yard is a commonly used method. This method leads to soil pollution, the emergence of various diseases in cattle, human beings, and plants [2]. However, composting of biological waste by microbial consortia can add various advantages. An anaerobic digestion process has been effectively utilized in China to manage MSW and China aimed to treat about 30,000 tonnes of waste food/day [3]. Recently, Huiru et al. [4] analyzedthe economic and technical feasibility of food waste digestion in anaerobic condition for electricity production in small plants. Agricultural fields are 
mainly exposed to various types of organic waste, which raise the increased possibility of isolation and screening of various microbial consortia with novel applications. Organic waste degradation requires enzymatic action of microorganisms to hydrolyze highly complex polymers into simpler degradable molecules. Hence, inoculation of biodegradable waste with various beneficial microorganisms, such as bacteria, fungi, and actinomycetes for the synthesis of extracellular enzymes, such as lipase, pectinase, protease, amylase, and cellulase, enhances the organic waste degradation rate [5]. This can be achieved by co-culturing various microorganisms and each organism contributes either way by synthesizing unique enzymes. The biodegradation of waste by the application of a microbial consortium is a classical method, and the level of degradation of organic waste by microbial species is based on its structural and functional stability of the biomass. Analysis of an efficient biodegrading consortium can be performed by antagonistic property, synergistic activity, and concomitant production of various hydrolytic enzymes [6].

In recent times, the environment has been severely affected by continuous application of pesticides and various synthetic fertilizers. The unrestricted use of various pesticides and inorganic fertilizers affects soil fertility, resulting in productivity loss. Hence, an alternate approach should be implemented to reverse soil fertility. The eco-friendly approach is an alternate method to reverse soil fertility and plant productivity using various microbes. These microorganisms reduce $\mathrm{C}: \mathrm{N}$ ratio and enhanced soil productivity [7]. Generally, the composting process involves many steps using diverse microbial consortia, such as fungi, bacteria, and Actinomycetes, collectively involved in humus formation. Composting is an eco-friendly method to reduce biodegradable organic waste into highly nutritious organic fertilizer. These organic fertilizers can be used as effective nutrients in vegetation [8].

Composted organic waste has generally been used to improve horticultural and agricultural soil to enhance crop growth and soil fertility. Also, composted nutrients effectively control soil-borne diseases. The applied compost suppressed soil-born plant pathogens and thus reduced the application of fungicides to the environment. Many mechanisms have been proposed to describe the control of soil-borne pathogens by compost, such as hyperparasitism, antibiotic production by various Streptomyces sp., and activation of disease-resistant genes of host plants [9]. Actinomycetes, mainly Streptomyces sp., have the potential to act against plant pathogens. These Streptomyces species are aerobic, Gram-positive bacterium and produce various antibiotics. It was estimated that more than $60 \%$ of the antimicrobial and antifungal agents developed for horticulture and agriculture have been extracted from Streptomyces spp. [10]. However, extensive hydrolytic enzyme screening on Streptomyces sp. and the composting process is limited. Until now, few chitinase-, cellulase- and antibiotics-producing organisms have been described from Actinobacteria. The genus Streptomyces is mainly considered as being able to produce many bioactive secondary metabolites that can effectively control various phytopathogens by improving endophytic or rhizosphere colonization [11]. Also, Streptomyces spp. enhances the bioavailability of various nutrients, alleviating abiotic stress and controlling phytopathogens. The antifungal secondary metabolites synthesized by Streptomyces showed activity against phytopathogens, such as Rhizoctoniasolani [12], due to the production of various enzymes and secondary metabolites. Actinomycetes can be used to enhance the availability of nutrients to the plants, which is an alternative to chemical fertilizers and pesticides.

\section{Materials and Methods}

\subsection{Soil Samples}

Tomato (Solanum lycopersicum) plant and rhizosphere-associated soil sample was collected from one plant pot using a sterile container. The surface soil was removed using a spatula and one sample (100 gm soil) was collected at approximately $10 \mathrm{~cm}$ depth. It was transported to the laboratory for analysis. Loosely adhered rhizosphere soil was removed and the tightly bound soil sample was subjected for the analysis of rhizosphere-associated Actinomycetes. 


\subsection{Isolation of Root-Associated Actinomycetes}

Isolation of actinomycetes was performed by standard method using $1.0 \mathrm{~g}$ air-dried rhizosphere-associated soil sample collected from the tomato plant [13]. A serially diluted sample was plated over the actinomycetes isolation media (AIM). AIM was amended with Nalidixic acid (50 $\mu \mathrm{g} / \mathrm{mL})$, Nystatin $(25 \mu \mathrm{g} / \mathrm{mL})$, and Fluconazole $(50 \mu \mathrm{g} / \mathrm{mL})$ to inhibit the growth of fungi and bacteria. All plates were incubated for 7 to 21 days at $28^{\circ} \mathrm{C}$. Morphologically distinct actinomycete isolate was purified further using the same medium and maintained in $20 \%$ glycerol and stored at $-80{ }^{\circ} \mathrm{C}$ for long-term use [14].

\subsection{Phytopathogens}

The phytopathogens, namely, Fusarium oxysporum, Aspergillus niger, Aspergillus flavus, Bipolaris oryzae, and Fusarium solani, were used. Inoculum of this spore suspension was prepared individually as suggested previously [15]. These fungal cultures were then stored on potato dextrose agar (PDA) slants.

\subsection{Antimicrobial Compounds Extraction and Screening}

The morphologically different ten actinomycetes isolates (Al-Dhabi 21, 22, 23, 24, 25, 26, 27, 28, 29, and 30) were cultivated into actinomycetes isolation broth and incubated for seven days at $28{ }^{\circ} \mathrm{C}$ and $150 \mathrm{rpm}$. After seven days, the culture was centrifuged at 10,000 rpm for $10 \mathrm{~min}$ and the supernatant used directly as the antimicrobial agents [16]. The extract was analyzed against plant pathogens (Fusarium oxysporum, Aspergillus niger, Aspergillus flavus, Bipolari soryzae, and Fusarium solani) using disc diffusion method as suggested by Kirby-Bauer with little modification. The antagonistic properties of the crude extract were compared with nystatinas the positive control. Antifungal property was evaluated by measuring the inhibitory zone of culture supernatant on the plates surface and the results reported were the mean of three independent repeats [17].

\subsection{Characterization of Potent Actinomycete Strain}

The strain Al-Dhabi 30 was selected for characterization studies based on its antagonistic potential. Morphological features, such as substrate and aerial mycelia, sporulation, and soluble pigments were analyzed after 7 days on ISP media. Assimilation of various sugars (arabinose, esquiline, starch, mannitol, rhamnose, raffinose, sucrose, and xylose), lipid hydrolysis, andmelanin production was analyzed. It was identified using phenotypic characters and $16 \mathrm{~S}$ rDNA sequencing. Genomic DNA of the isolate Al-Dhabi 30was extracted as suggested by Wilson [18] and sequenced using forward (27) and reverse (1525) primers, as described by Lane [19].

\subsection{Screening and Quantification of Plant Growth-Promoting Activity of Actinomycetes}

The phosphate solubilising property of the selected actinomycetes was analyzed using PKV agar media. After 5 days of incubation, a clear zone around the actinomycetes colonies indicated phosphate solubilising activity [20]. The positive strains were further cultured in National Botanical Research Institute Phosphate (NBRIP) broth medium and incubated for 8 days at $28^{\circ} \mathrm{C}$ at $175 \mathrm{rpm}$ using an orbital shaker incubator. The culture was centrifuged and the absorbance was checked using a UV-visible spectrophotometer at $880 \mathrm{~nm}$ [21]. Potassium dihydrogen phosphate $\left(\mathrm{KH}_{2} \mathrm{PO}_{4}\right)$ was used as the standard and the results are expressed as $\mathrm{mg}$ phosphate/dL. The siderophore production by the selected Actinomycetes isolates was performed as described by Schwyn and Neilands [22], with minor modifications. Chrome azurol $\mathrm{S}$ agar medium was prepared and the culture was inoculated and incubated for 6 days at $28^{\circ} \mathrm{C}$. Siderophore production was confirmed by the development of halo zone of yellow-orange colour. Further, sideropore-producing strains were separately cultured in Gaus No. 1 medium with little modification [23]. The culture was incubated for $10-12$ days at $28^{\circ} \mathrm{C}$ in an orbital shaker at $175 \mathrm{rpm}$. The Csaky method [24] was used for the determination of siderophores. Indole acetic acid-producing ability of Actinomycetes was determined. Actinomycetes were grown 
on ISP2 medium and incubated for 8 days at $28^{\circ} \mathrm{C}$. Then, a cork borer was used to cut the agar at $6 \mathrm{~mm}$ diameter. It was inoculated into ISP-2 liquid medium containing $0.2 \%$ L-tryptophan. The culture was incubated for 15 days at $28^{\circ} \mathrm{C}$ using an orbital shaker at $175 \mathrm{rpm}$. Then, it was centrifuged at $10,000 \mathrm{rpm}$ for $10 \mathrm{~min}$ and the clear supernatant was used for analysis. A $1 \mathrm{~mL}$ culture supernatant was mixed with $2 \mathrm{~mL}$ of Salkowski's reagent and kept in the dark for $30 \mathrm{~min}$ at $30 \pm 2{ }^{\circ} \mathrm{C}$. The developed red or pink colour was measured at $530 \mathrm{~nm}$ using a UV-visible spectrophotometer. The amount of IAA $(\mu \mathrm{g} / \mathrm{mL})$ from the culture supernatant was calculated using indole-3-acetic acid as the standard [25].

\subsection{Hydrolytic Enzyme Screening and Assay from Actinomycetes}

The morphologically different Actinomycetes species (Al-Dhabi 21, 22, 23, 24, 25, 26, 27, 28, 29, and 30) were analyzed for their ability to produce various hydrolytic enzymes. The isolates were grown on substrate agar plates $(1 \%, w / v$, casein, cellulose, pectin, colloidal chitin, and starch) for the determination of protease, cellulase, pectinase, chitinase, and amylase activity. The plates were incubated for 7 days and detected enzyme activity. Protease-positive Actinomycetes isolate shows halo zone around the isolated strain, whereas cellulase activity was determined after flooding with $0.1 \%$ Congo red (20 min incubation), and developing with $1 \mathrm{M} \mathrm{NaCl}$ (10 min). Gram's Iodine solution was flooded with starch agar plates for the determination of amylase activity. Pectinase-producing Actinomycetes were detected by adding iodine solution with pectin plates. Chitinase-producing ability of the strains was analyzed using colloidal chitin agar medium [26]. The selected ten actinomycetes isolates were inoculated in minimal medium and incubated for 7 days at $28{ }^{\circ} \mathrm{C}$. To induce concomitant enzyme production, the substrates, such as casein, starch, pectin, chitin, and cellulose, were supplemented with the medium at $0.5 \%(w / v)$ level.

Pectinase activity of the sample was determined using pectin as a substrate. About $9.8 \mathrm{~mL}$ pectin $(0.5 \%)$ was mixed with $0.2 \mathrm{~mL}$ culture supernatant. It was incubated for $10 \mathrm{~min}$ and $1 \mathrm{~mL}$ sodium carbonate $(1 \mathrm{M}), 5 \mathrm{~mL}$ iodine $(0.1 \mathrm{~N})$ were added and kept for $5 \mathrm{~min}$. To this, $2 \mathrm{~mL}$ sulphuric acid $(2 \mathrm{~N})$ was added and kept in the dark for $15 \mathrm{~min}$. The developed dark colour was further titrated against sodium thio sulphate $(0.1 \mathrm{M})$ using soluble starch $(1 \%)$ as an indicator. Protease activity of culture supernatant was assayed using casein $(1 \%)$ as a substrate. The substrate was prepared in Tris buffer ( $\mathrm{pH} 8.0,50 \mathrm{mM}$ ). Then, $1.0 \mathrm{~mL}$ casein was mixed with $0.1 \mathrm{~mL}$ culture supernatant and incubated for $30 \mathrm{~min}$. Then, $10 \%(w / v)$ trichloro acetic acid $(5 \mathrm{~mL})$ was added and incubated for $30 \mathrm{~min}$. It was centrifuged at $5000 \mathrm{rpm}$ for $5 \mathrm{~min}$ and the supernatant was measured at $275 \mathrm{~nm}$ against reagent blank using a UV-visible spectrophotometer. L-tyrosine was used as the standard for the determination of protease activity. Cellulase activity of the sample was assayed using $1 \%$ carboxy methyl cellulose $(\mathrm{CMC})$ as a substrate. This substrate was prepared in $50 \mathrm{mM}$ sodium phosphate buffer (pH 7.0); $1.0 \mathrm{~mL}$ substrate was mixed with $0.1 \mathrm{~mL}$ culture supernatant and incubated for $30 \mathrm{~min}$; $1.0 \mathrm{~mL}$ dinitro salicylic acid (DNS) was added and kept on boiling water bath for $10 \mathrm{~min}$. Brick red color was developed and diluted with $10 \mathrm{~mL}$ double-distilled water. The absorbance was read at $540 \mathrm{~nm}$ against reagent blank. Amylase was assayed from the culture supernatant using soluble starch as a substrate. Next, $1 \%$ soluble starch was prepared in sodium phosphate buffer $(\mathrm{pH} 7.0,50 \mathrm{mM})$. To the substrate $(1 \mathrm{~mL})$, a $0.1 \mathrm{~mL}$ sample was added and incubated for $30 \mathrm{~min}$. Further enzyme assay was continued following a similar procedure to the cellulase assay. Chitinase activity of the culture supernatant was determined using colloidal chitin as a substrate. This substrate was prepared at the $1 \%$ level using $50 \mathrm{mM}$ acetate buffer ( $\mathrm{pH}$ 5.5). A $1.0 \mathrm{Ml}$ substrate was mixed with a $0.1 \mathrm{~mL}$ sample and incubated for $30 \mathrm{~min}$. After that, $1.0 \mathrm{~mL}$ DNS was added and further assay was continued following a similar procedure to the cellulase assay.

\subsection{Vegetable Waste Compostingand Physio-Chemical and Biological Properties}

In composting, the nature of the raw material directly influences the quality of the mature compost. The vegetable waste, such as cabbage, cucumber, cauliflower leaves, and brinjal waste were collected, dried, mechanical blended, and water was sprayed for microbial composting. Then, 
$5.0 \mathrm{~kg}$ of vegetable waste was used for the composting process. The microbial consortium, including rhizosphere-associated Streptomyces sp. Al-Dhabi 30, Candida utilis ATCC 9950, and Lactobacillus plantarum ATCC 33222, were added with vegetable waste, whereas Streptomyces sp. Al-Dhabi 30 was not inoculated in the control. However, the control vegetable waste was amended with C. utilis ATCC 9950 and L. plantarum ATCC 33222. The selected microorganisms have a known producer of various enzymes and have the ability to degrade vegetable waste during composting, whereas Streptomyces sp. Al-Dhabi 30 has the potential to synthesize plant growth promoting substances, including antibiotics. Microbial composting vegetable waste was performed for 42 days. Finally, the mature compost was subjected to physical, chemical properties, antifungal activities, followed by plant growth promoting activities [4]. Moisture content of the compost was tested by standard method. Compost was taken in a container and dried in an oven at $110{ }^{\circ} \mathrm{C}$ until constant weight was achieved and percentage moisture level was calculated. The nutrient factors, such as organic carbon (\%), nitrogen (\%), carbon and nitrogen ratio, $\mathrm{pH}$ and electrical conductivity (EC), were determined. To the mature compost, double-distilled water was added at 1:10 (w/v) ratio and kept on rotary shaker at $200 \mathrm{rpm}$ for $30 \mathrm{~min}$. This sample was used for nutrient and antagonistic activity analysis. Nitrogen content was estimated by the Kjeldahl method, as suggested by Bremner [27]. Organic carbon content in the compost was tested by the method of Walkey and Black [28]. Antagonistic activity of the mature compost was determined using the well diffusion method [15].

\subsection{Analysis of Plant Growth Promoting Activity of Compost}

The experimental compost amended with Streptomyces sp. Al-Dhabi 30and control compost was used for analysis. The selected tomato plant seed $(n=20)$ was sterilized and prepared according to the method of Indananda et al. 2010 [29]. The seeds were supplied with required water for germination and allowed for 4-5 days under dark condition. After 15 days of seed germination, mature compost was supplied into the experimental pot, whereas control compost was added with the control pot. Treatment was continued for three weeks and growth performance (shoot length, root length, and weight) were analyzed. Results were analyzed using one-wayanalysis of variance (ANOVA) with posthoc Tukey HSD test.

\section{Results}

\subsection{Actinomycetes and Their Antagonistic Properties Against the Selected Phytopathogens}

The antagonistic property of the Actinomycetes was tested against five plant pathogens. In total, 37 Actinomycetes were successfully recovered from the rhizosphere-associated soil. Among the 37 Actinomycetes isolates, only ten Actinomycetes showed activity against at least one phytopathogen. About $65 \%$ isolates showed potent antifungal activity against $F$. xysporum, F. solani, and A. niger, five strains showed activity against F. oxysporum, A. niger, A. flavus, and Bipolaris oryzae. In the present investigation, one Actinomycete (Streptomyces sp. Al-Dhabi 30) showed potent activity against all tested plant pathogens. Antifungal activity and the corresponding zone of inhibition $(\mathrm{mm})$ were presented in Table 1. The molecular level characterization of the strain by $16 \mathrm{~S}$ rRNA gene sequence amplification and sequencing confirmed that the strain belonged to the Streptomyces species and the obtained sequence was publicly available in PubMed, with the accession number $16 \mathrm{~S}$ rDNA sequence deposited in GenBank under the accession number MN709219. 
Table 1. Antagonistic activity of Actinomycetes (Zone of inhibition in $\mathrm{mm}$ ) isolated from root-associated soil of tomato plantagainst phytopathogens.

\begin{tabular}{cccccc}
\hline Actinomycetes & \multicolumn{5}{c}{ Antagonistic Activity $(\mathbf{m m})$} \\
\hline & F. oxysporum & A. niger & A. flavus & B. oryzae & F. solani \\
\hline $\begin{array}{c}\text { Streptomyces sp. } \\
\text { Al-Dhabi 21 }\end{array}$ & 22 & 11 & 0 & 0 & 17 \\
$\begin{array}{c}\text { Streptomyces sp. } \\
\text { Al-Dhabi 22 }\end{array}$ & 0 & 0 & 18 & 17 & 0 \\
$\begin{array}{c}\text { Streptomyces sp. } \\
\text { Al-Dhabi 23 }\end{array}$ & 19 & 16 & 12 & 0 & 0 \\
$\begin{array}{c}\text { Actinomycete } \\
\text { Al-Dhabi 24 }\end{array}$ & 0 & 16 & 22 & 19 & 0 \\
$\begin{array}{c}\text { Actinomycete } \\
\text { Al-Dhabi 25 }\end{array}$ & 0 & 0 & 20 & 20 & 17 \\
$\begin{array}{c}\text { Streptomyces sp. } \\
\text { Al-Dhabi 26 }\end{array}$ & 19 & 21 & 17 & 0 & 0 \\
$\begin{array}{c}\text { Streptomyces sp. } \\
\text { Al-Dhabi 27 }\end{array}$ & 12 & 0 & 0 & 0 & 18 \\
$\begin{array}{c}\text { Streptomyces sp. } \\
\text { Al-Dhabi 28 }\end{array}$ & 0 & 0 & 17 & 18 & 0 \\
$\begin{array}{c}\text { Streptomyces sp. } \\
\text { Al-Dhabi 29 }\end{array}$ & 18 & 19 & 21 & 0 & 0 \\
Streptomyces sp. & 22 & 17 & 16 & 21 & 20 \\
$\quad$ Al-Dhabi 30 & & & &
\end{tabular}

\subsection{Production of Plant Growth Promoting Factors by Actinomycetes}

Antagonistic Actinomycetes (Al-Dhabi 21, 22, 23, 24, 25, 26, 27, 28, 29, and 30) were subjected for the synthesis of IAA in the minimal medium. Among these 10 Actinomycetes isolates, 8 actinomycetes were able to produce IAA. IAA production ranged between 5 and $43 \mu \mathrm{g} / \mathrm{mL}$ (Table 2). The strain Streptomyces sp. Al-Dhabi 30 showed the ability to produce a maximum amount of IAA $(43 \mu \mathrm{g} / \mathrm{mL})$ among the tested actinomycetes species. The selected ten actinomycetes were subjected to screen the ability to solubilise inorganic phosphate from the medium. All selected Actinomycetes showed the ability to solubilise phosphate. Phosphate degrading ability was maximum in Streptomyces sp. Al-Dhabi $30(43.1 \mathrm{mg} / \mathrm{dL}$ ) (Table 2). Siderophore production was detected from $80 \%$ of the selected isolates. These isolates formed a clear orange zone around the Actinomycetes colony. Eight Actinomycetes produced siderophore and the concentration ranged between 1.6 and $42.1 \mu \mathrm{g} / \mathrm{mL}$. Among the Streptomyces species, Streptomyces sp. Al-Dhabi 30 produced the maximum amount $(42.1 \mu \mathrm{g} / \mathrm{mL})$ of siderophore (Table 2).

Table 2. Plant growth promoting activity of Actinomycetes isolated from the root-associated soil from tomato plant.

\begin{tabular}{cccc}
\hline \multicolumn{1}{c}{ Actinomycetes } & Plant Growth Promoting Activity & \\
\hline & IAA $(\boldsymbol{\mu g} / \mathbf{m L})$ & Phosphate Solubilizing $(\mathbf{m g} / \mathbf{d L})$ & Siderophore $(\boldsymbol{\mu g} / \mathbf{m L})$ \\
\hline Streptomyces sp. Al-Dhabi 21 & 12 & 10 & 1.6 \\
Streptomyces sp. Al-Dhabi 22 & 0 & 21 & 0 \\
Streptomyces sp. Al-Dhabi 23 & 9 & 9 & 18.2 \\
Actinomycete Al-Dhabi 24 & 32 & 14.5 & 40.2 \\
Actinomycete Al-Dhabi 25 & 3 & 39 & 2.42 \\
Streptomyces sp. Al-Dhabi 26 & 19 & 27 & 2.3 \\
Streptomyces sp. Al-Dhabi 27 & 21 & 12.1 & 5.67 \\
Streptomyces sp. Al-Dhabi 28 & 5 & 4.2 & 0 \\
Streptomyces sp. Al-Dhabi 29 & 0 & 9.2 & 1.9 \\
Streptomyces sp. Al-Dhabi 30 & 43 & 43.1 & 42.1 \\
\hline
\end{tabular}




\subsection{Enzyme Production by Actinomycetes}

The selected all ten actinomycetes showed protease production. Of them all, strain Al-Dhabi 30 showed $19 \mathrm{~mm}$ zone in casein agar plates. Also, enzyme production was found to be maximum $(121 \mathrm{U} / \mathrm{mL})$ in Streptomyces sp. Al-Dhabi 30. Cellulase production ranged between $18 \mathrm{U} / \mathrm{mL}$ and $67 \mathrm{U} / \mathrm{mL}$. Only about $60 \%$ of the selected actinomycetes strains were able to hydrolyze cellulose material. Pectinase production was maximum in Streptomyces sp. Al-Dhabi $22(2.1 \mathrm{U} / \mathrm{mL})$ compared to other isolates. Also, three Actinomycetes did not show any pectinase activity in the culture supernatant. All selected Actinomycetes species showed amylase activity and ranged between 0.3 and $19.2 \mathrm{U} / \mathrm{mL}$ (Table 3).

Table 3. Production of extracellular enzymes by Actinomycetes species isolated from the root-associated soil from tomato plant.

\begin{tabular}{cccccc}
\hline Actinomycetes & \multicolumn{5}{c}{ Enzyme Activity (U/mL) } \\
\hline & Protease & Cellulase & Pectinase & Amylase & Chitinase \\
\hline Streptomyces sp. Al-Dhabi 21 & 42 & 0 & 1.8 & 0.3 & 29.4 \\
Streptomyces sp. Al-Dhabi 22 & 110 & 0 & 2.1 & 19.2 & 0 \\
Streptomyces sp. Al-Dhabi 23 & 48 & 52 & 0 & 13 & 40.2 \\
Actinomycete Al-Dhabi 24 & 19 & 0 & 0.43 & 12 & 0 \\
Actinomycete Al-Dhabi 25 & 56 & 42 & 2 & 10.5 & 29.2 \\
Streptomyces sp. Al-Dhabi 26 & 43 & 18 & 1.1 & 9.5 & 35.9 \\
Streptomyces sp. Al-Dhabi 27 & 10 & 0 & 0 & 5 & 0 \\
Streptomyces sp. Al-Dhabi 28 & 2.1 & 38 & 0.2 & 10.2 & 25.5 \\
Streptomyces sp. Al-Dhabi 29 & 92.5 & 22 & 0 & 4.2 & 19.4 \\
Streptomyces sp. Al-Dhabi 30 & 121 & 67 & 1.3 & 13.4 & 43.7 \\
\hline
\end{tabular}

\subsection{Characterization of Actinomycetes}

The suitable plant growth promoting strain Al-Dhabi 30was characterized by morphological, biochemical, and 16S rDNA sequencing and identified as Streptomyces sp. Al-Dhabi 30. It produced aerial mycelium and was ash colour. It was a non-acid fast organism, Gram-positive. Sporulation was observed on solid media; this organism produced filamentous and highly branched mycelium. It was catalase-positive and reduced nitrate effectively. It hydrolyzed arabinose, mannitol, rhamnose, raffinose, sucrose, xylose, esquiline, and starch and failed to hydrolyze lipid substrate. The strain Al-Dhabi 30 could hydrolyze maltose, lactose, glucose, mannitol, and salicin.

\subsection{Composting of Vegetable Waste}

The vegetable waste decomposition started after inoculation of vegetable waste with microbial consortium. Biodegradation of waste was observed after the 7th day of incubation due to fungal and Actinomycetes growth. In the experimental compost, degradation was rapid and a sharp decrease in decolouration, changes in physical texture and volume also decreased considerably. These rapid changes inferred the use of Streptomyces sp. in waste composting. The vegetable waste was completely decomposed after 42 days of incubation and about $\frac{3}{4}$ volume decreased during this period. Total nitrogen content (\%) was $2.7 \%$ in the control, whereas $3.8 \%$ organic carbon was detected in the experiment. In the compost vegetable waste, the C:N ratio was $10.07 \%$, whereas it was $17.51 \%$ in the controlafter 42 days. The compost was extracted with water at a 1:10 ratio (compost and water) and it showed antagonistic activity against the selected fungal pathogens (F. xysporum, A. niger, A. flavus, B. oryzae, and F. solani). These phenomena clearly suggested the antibiotic potential of Streptomyces sp. Al-Dhabi 30. The physiochemical properties and antifungal potential of compost is described in Table 4. 
Table 4. Physical, chemical, and biological properties of mature compost.

\begin{tabular}{ccc}
\hline Parameters & Control & Experiment \\
\hline Physical properties & & \\
Colour & Brownish black & Black \\
Moisture & 17.42 & 34.49 \\
Chemical properties & & \\
pH & 7.4 & 7.48 \\
Electrical conductivity & & \\
(ds/m) & 4.1 & 4.5 \\
Nitrogen (as N\%) & 2.7 & 3.8 \\
Organic carbon (\%) & 47.28 & 38.29 \\
C:N ratio & 17.51 & 10.07 \\
Antifungal activity & & \\
F. oxysporum & - & +++ \\
A. niger & - & +++ \\
A. flavus & + & +++ \\
B. oryzae & - & +++ \\
F. solani & - & +++ \\
\hline
\end{tabular}

- indicates negative, +indicates low activity and +++indicates high activity.

\subsection{Experimental Trial of Plant Growth Analysis Treated with Compost}

The efficacy of Streptomyces sp. Al-Dhabi 30 promoting plant growth was determined at 42 days after planting. Tomato plant treated with experimental compost showed better effect than control pots. The vegetable waste together composed by Streptomyces sp. Al-Dhabi 30 enhanced shoot and root lengthcompared to control seedlings after 21 days of sprouting. The root length of the control tomato plant was $1.92 \pm 0.26 \mathrm{~cm}$ and the length was increased in the Streptomyces sp. Al-Dhabi 30 inoculated compost $(2.87 \pm 0.32 \mathrm{~cm})(p<0.0001)$. Likewise, the shoot length was $13.4 \pm 0.42 \mathrm{~cm}$ in the control tomato plant, whereas $17.1 \pm 0.22 \mathrm{~cm}$ in the tomato plant treated with Streptomyces sp. Al-Dhabi 30 compost after 42 days $(p<0.001)$. Likewise, the total weight of the plant also increased about $15 \%$ in the Streptomyces sp. Al-Dhabi 30 compost vegetable waste. Collectively, Streptomyces sp. Al-Dhabi 30-assisted compost mediated plant growth promotionand the results were statistically significant $(p<0.01)$. Growth promoting activity of compost on the growth of tomato plant is described in Table 5.

Table 5. Effect of Streptomyces sp. Al-Dhabi 30 on growth promoting activity in tomato plant.

\begin{tabular}{|c|c|c|c|}
\hline Experimental Procedure & Root Length (cm) & Shoot Length (cm) & Total Weight of Plant (gm) \\
\hline \multicolumn{4}{|l|}{21 days treatment } \\
\hline Control & $1.92 \pm 0.26$ & $6.9 \pm 0.33$ & $1.92 \pm 0.53$ \\
\hline Treatment & $2.87 \pm 0.32 * * * *$ & $9.42 \pm 0.28^{* * * *}$ & $3.1 \pm 0.41^{* * *}$ \\
\hline \multicolumn{4}{|l|}{28 days treatment } \\
\hline Control & $2.4 \pm 0.32$ & $7.42 \pm 0.29$ & $2.53 \pm 0.38$ \\
\hline Treatment & $3.82 \pm 0.28^{* * * *}$ & $11.32 \pm 0.18^{* * * *}$ & $4.6 \pm 0.26^{*}$ \\
\hline \multicolumn{4}{|l|}{35 days treatment } \\
\hline Control & $3.6 \pm 0.39$ & $11.2 \pm 0.11$ & $3.1 \pm 0.23$ \\
\hline Treatment & $4.9 \pm 0.41^{* * *}$ & $15.2 \pm 0.13^{* *}$ & $5.3 \pm 0.47^{* *}$ \\
\hline \multicolumn{4}{|l|}{42 days treatment } \\
\hline Control & $5.1 \pm 0.33$ & $13.4 \pm 0.42$ & $4.76 \pm 0.31$ \\
\hline Treatment & $6.8 \pm 0.27^{* * * *}$ & $17.1 \pm 0.22 * *$ & $6.21 \pm 0.29 *$ \\
\hline
\end{tabular}




\section{Discussion}

A total of 37 Actinomycetes were isolated from the root-associated soil of tomato plant. These relatively large numbers of Actinomycetes suggested that rhizosphere is an important source of Actinomycetes. These plant-associated actinomycetes have the potential activity against various phytopathogens. Of these, five Actinomycetes strains have potent activity against F. oxysporum, A. niger, A. flavus, and B. oryzae. Among all tested isolates, Streptomyces sp. Al-Dhabi 30 showed potent activity against F. oxysporum, A. niger, A. flavus, B. oryzae, and F. solani. Streptomyces species produce various metabolites and are highly active against $R$. solani [12]. In a study, Verma et al. 2009, [30] isolated endophytic Actinomycetes from A. indica, A. Juss, and the isolated Streptomyces sp. showed antimicrobial activity. Recent studies indicated that the Streptomyces strains revealed protective bioactivity against various microbial pathogens also [31,32]. The present finding and earlier studies $[33,34]$ showed that Streptomyces is the predominant organism in endophytic form or associated with root.

In recent years' application of chemical fertilizers, herbicides and pesticides increased rapidly and are a serious concern in crop production and environmental management. Hence, industrialists and researchers seek an alternate approach using natural resources for the sustainable production of agricultural products in horticulture and agriculture [33]. It was found that plant-associated actinomycetes have various responses, including plant growth promoting activity. In a study, Verma et al. [34] reported on the growth promoting property of actinomycetes species. The selected ten antagonistic Actinomycetes were synthesized using IAA, effectively solubilised inorganic phosphates and producing siderophore. These growth promoters enhanced the growth performance of plants. The selected actinomycetes showed potential antifungal activity and plant growth promoting potential. Among 10 actinomycetes, eight organisms effectively produced plant growth promoting biomolecules. Of these, seven isolates were identified as Streptomyces sp.; especially, root associated with Streptomyces sp. Al-Dhabi 30 has the potential to produce plant growth promoting molecules, such as IAA, siderophore, and phosphate solubilising property. These findings are in good agreement with previous studies by Hamdali et al. [35], who detected 39, 58.9, $83.3 \mathrm{mg} / \mathrm{dL}$ phosphate solubilisation by Micromonospora aurantiaca, Streptomyces griseus, and Streptomyces cavourensis, respectively. In a study, Chen et al. [36] reported phosphate solubilising property of bacteria from the subtropical soil and analyzed their tricalcium phosphate solubilising abilities. Also, they reported the influence of phosphate solubilising organisms in acidification of the medium, and stated that the soluble phosphate concentration and $\mathrm{pH}$ of the medium were inversely proportional. This leads to the production of gluconic acid, a very low molecular weight organic acid. Hence, the plant-associated Actinomycetes play a very important role in the growth of plants.

The screened Actinomycetes, mainly Streptomyces species, produced a considerable amount of siderophores. These siderophores have the potential to inhibit the growth of phytopathogens. The growth of phytopathogen inhibiting property by Streptomyces species due to the production of siderophores has been described previously [31]. Tan et al. [37] reported that synthesis of siderophore for the growth of the plant and phytopathogen antagonism Streptomyces sp. Al-Dhabi 30 produced a maximum level of siderophore, and these results are in good agreement with previous reports. Nimnoi et al. [38] reported that Pseudonocardia halophobica showed a high amount of siderophore producing ability $(39.30 \mu \mathrm{g} / \mathrm{mL})$. However, the amount of siderophores production in the present study was found to be higher than previous reports, suggesting the growth promoting potential of the Streptomyces sp. Al-Dhabi 30. In a study, Khamna et al. [39] reported hydroxamate type and catechol types siderophore from Streptomyces CMU-SK 126 isolated from Curcuma mangga rhizospheric soil.

The phosphate solubilisation property was found to be high in the Streptomyces sp. Al-Dhabi 30 compared toother actinomycetes isolates. The production of IAA varied between 3 and $43 \mu \mathrm{g} / \mathrm{mL}$ and this range is in accordance with observations made previously by various research groups. Nimnoi et al. [40] reported IAA-producing bacteria associated with rhizosphere, root tissue and rhizoplane of Leucaena leucocephala, Ficu sreligiosa L., and Piper sarmentosum Roxb. Khamna et al. [39] 
isolated Actinobacteria from rhizosphere soil and showed the ability to produce siderophore, IAA, and various antifungal compounds. Recently, Verma et al. [34] isolated plant growth promoting Streptomyces from Azadirachtaindica A. Juss and reported the ability to inhibit the growth of phytopathogens. Actinomycetes, mainly the genus Streptomyces, has a lot of potential to produce various phytohormones, secondary metabolites against phytopathegens and this lead showsa lot of advantages to colonize to rhizosphere [11].

The selected substrates were added with the minimal medium for the production of various enzymes because most of the enzymes are inducible. About $70 \%$ of the actinomycetes were synthesized chitinase enzyme. This enzyme is very important for the hydrolysis and recycling of nitrogen and carbon trapped in an insoluble form of chitin and it is also widely used for making biopesticides and mosquito control [41]. Protease production ranged between 2.1 and $121 \mathrm{U} / \mathrm{mL}$, and all the selected actinomycetes were synthesized protease. Of these, only six isolates produced cellulases and Streptomyces sp. Al-Dhabi 30 produced the maximum amount $(67 \mathrm{U} / \mathrm{mL})$. Pectinase production ranged between $0.43 \mathrm{U} / \mathrm{mL}$ and $2.1 \mathrm{U} / \mathrm{mL}$. Streptomyces sp. Al-Dhabi 22 produced the maximum amount of amylase compared to strain Al-Dhabi 30. However, protease, cellulase, and chitinase activity was maximum in Streptomyces sp. Al-Dhabi 30. Considering this fact, strain Al-Dhabi 30 has the potential to degrade organic biomass from the environment. In a study, Gopinath et al. [42] analyzed the biodegrading ability of organic waste, tested by assaying various hydrolytic enzymes. These hydrolytic enzymes are useful in the composting process and help to breakdown complex molecules to simpler ones.

The vegetable waste compost was made after inoculation with antifungal compound-producing Streptomyces sp. Al-Dhabi 30. Biodegradation of waste was visible, the colour changed to brown and volume also decreased from two weeks of composting. The carbon and nitrogen ratio decreased in the experimental compost from 17.51 to $10.07 \%$. It shows the potential composting properties of Streptomyces sp. Al-Dhabi 30 on vegetable waste. Kitchen waste, vegetable waste have been used previously by various research groups for composting. In a study, Karnchanawong and Nissaikla [43] used organic waste for the preparation of compost using microbial consortia and improved composting was achieved using mature compost as a starting material, because these mature types of compost consist of various microbial consortia, including Actinomycetes. In a study, Actinomycetes consortium alone was used to compost domestic agro-residues and the mature compost has been used to treat pulp-paper mill effluent [44]. Theseprevious studies reported composting of agro-waste without bacteria and fungi. Previously, Tanaka et al. [45] reported that Micromonospora sp. and Streptomyces sp. completely degraded yeast debris. These previous literatures and present finding show the efficiency of Streptomyces sp. Al-Dhabi 30 on composting. Kitchen waste contains mainly agro-industrial residues. These residues are composed of large proportions of lignin (10-35\%), hemicelluloses (15-35\%) and cellulose (35-50\%) [46]. In general, naturally associated microbial consortia accelerated composting process. Considering this fact, tomato root-associated soil sample has been used for the isolation of Actinomycetes. Generally, bacteria, fungi, and Actinomycetesare involved in the composting process, because all these three exist in the natural environment. In this work, an attempt was made to use enzyme-producing thermophilic actinomycete along with microbial consortium to compost vegetable waste to obtainantifungal and growth-promoting compost. During the composting process, high heat is generated during the middle phase and the population of mesophilic organisms was found to be less at this stage. However, inoculation of thermophilic Actinomycete could improve the degradation potential of the compost. Actinomycete strain Al-Dhabi 30 was selected for composting based on its rapid growth compared to other species. Also, this organism was able to synthesize various hydrolytic enzymes influencing composting. The group of enzymes, including cellulases, amylases, proteases, chitinases, and pectinases, involved breakdown of all lignocelluostic materials from the vegetable waste.

In this observation, Streptomyces sp. Al-Dhabi 30 composed nutrients showed the ability to produce significant plant growth promoting activity under experimental conditions. This actinomycete 
species showed the maximum root and shoot length of experimental plant compared to the control plant after 21, 28, 35, and $42 \mathrm{~d}$ of sprouting. These findings indicated the plant growth promoting activity of Streptomyces sp. Al-Dhabi 30 compost vegetable waste. Root and shoot length was found to be less in the control experiment. These kinds of plant growth promoting Actinomycetes could improve the bioavailability of nutrients and be alternates to fertilizers and chemical pesticides and has been reported previously [47]. In this experiment, the actinomycetes colonized tomato plant and promoted plant growth through biosynthesis of various growth promoters, such as IAA and siderophores, and also have potential activity against various plant pathogens. These synthesized compounds enhanced the growth of shoot and root. In the experimental tomato plant, root length increased 33\%, whereas shoot length was enhanced $27 \%$ after six weeks. Many previous reports stated that Actinobacteria can enhance shoot and root length in various plants, and such an increase may show advantages to the plants to promote growth and biocontrol efficacy. In a study, Lamsal et al. [48] reported influential growth in tomato using rhizobacterial isolates, where root and shoot length was $26 \%$ and $18 \%$ higher, respectively, than the control. This kind of phytopathogen control property can manifest as space and nutrient competition, predation, induced systemic resistance, hypovirulence, and parasitism [49]. All these mechanisms indirectly enhance the growth of plants. Biocontrol property is very important and it has been reported as the first and foremost important to colonize the root tip of plants. Taken together, the findings of these studies show that Streptomyces sp. Al-Dhabi 30 is highly suited as a potent plant growth promoting and biocontrol inoculum for sustainable agriculture.

\section{Conclusions}

From this study, we conclude that various Streptomyces species, including Streptomyces sp. Al-Dhabi 30 associated with root of tomato plant have tremendous potential as an antagonistic agent against F. oxysporum $(22 \mathrm{~mm})$ and B. oryzae $(21 \mathrm{~mm})$. The Streptomyces sp. Al-Dhabi 30 effectively produced indoleacetic acid $(43 \mu \mathrm{g} / \mathrm{mL})$ and siderophores $(42.1 \mu \mathrm{g} / \mathrm{mL})$. The total weight of tomato increased over $15 \%$ compared to the control compost and was statistically significant. The selected microbial consortium has the potential to degrade vegetable waste and enrich the compost with phytohormones and antagonistic secondary metabolites. This compost is useful as potential plant growth promoting activity.

Author Contributions: N.A.A.-D. and M.V.A. designed and supervised the experiment. N.A.A.-D., G.A.E., M.V.A., and A.-K.M.G. performed the laboratory work. N.A.A.-D. and M.V.A. analyzed the results and drafted the manuscript.

Funding: The authors are grateful to the Deanship of Scientific Research, King Saud University for funding through the Vice Deanship of Scientific Research Chairs.

Acknowledgments: The authors are grateful to the Deanship of Scientific Research, King Saud University for funding through the Vice Deanship of Scientific Research Chairs.

Conflicts of Interest: The authors declare no conflict of interest.

\section{References}

1. Zhou, H.; Meng, A.; Long, Y.; Li, Q.; Zhang, Y. An overview of characteristics of municipal solid waste fuel in China: Physical, chemical composition and heating value. Renew. Sustain. Energy Rev. 2014, 36, $107-122$. [CrossRef]

2. Forastiere, F.; Badaloni, C.; Hoogh, K.D.; Kraus, M.K.; Martuzzi, M.; Mitis, F. Health impact assessment of waste management facilities in three European countries. Environ. Health 2011, 10, 53. [CrossRef] [PubMed]

3. Xu, C.; Shi, W.; Hong, J.; Zhang, F.; Chen, W. Life cycle assessment of food waste-based biogas generation. Renew. Sustain. Energy Rev. 2015, 49, 169-177. [CrossRef]

4. Huiru, Z.; Yunjun, Y.; Liberti, F.; Pietro, B.; Fantozzi, F. Technical and economic feasibility analysis of an anaerobic digestion plant fed with canteen food waste. Energy Convers. Manag. 2019, 180, 938-948. [CrossRef]

5. Saha, A.; Santra, S.C. Isolation and characterization of bacteria isolated from municipal solid waste for production of industrial enzymes and waste degradation. J. Microbiol. Exp. 2014, 1, 1-8. [CrossRef] 
6. Sarkar, P.; Meghvanshi, M.; Singh, R. Microbial consortium: A new approach in effective degradation of organic kitchen wastes. Int. J. Environ. Sci. Dev. 2011, 2, 170-174. [CrossRef]

7. Umsakul, K.; Dissara, Y.; Srimuang, N. Chemical physical and microbiological changes during composting of the water hyacinth. Pak. J. Biol. Sci. 2010, 13, 985-992. [CrossRef]

8. Zeng, G.; Yu, Z.; Chen, Y.; Zhang, J.; Li, H.; Yu, M.; Zhao, M. Response of compost maturity and microbial community composition to pentachlorophenol (PCP)-contaminated soil during composting. Bioresour. Technol. 2011, 102, 5905-5911. [CrossRef]

9. Maher, M.; Prasad, M.; Raviv, M. Organic soilless media components. In Soilless Culture: Theory and Practice; Raviv, M., Lieth, J.H., Eds.; Elsevier BV: Oxford, UK, 2008; pp. 459-504.

10. Hwang, B.K.; Lim, S.W.; Kim, B.S.; Lee, J.Y.; Moon, S.S. Isolation and in vivo and in vitro antifungal activity of phenylacetic acid and sodium phenylacetate from Streptomyces humidus. Appl. Environ. Microbiol. 2001, 67, 3739-3745. [CrossRef]

11. Golinska, P.; Dahm, H. Antagonistic properties of Streptomyces isolated from forest soils against fungal pathogens of pine seedlings. Dendrobiology 2013, 69. [CrossRef]

12. Kanini, G.S.; Katsifas, E.A.; Savvides, A.L.; Hatzinikolaou, D.G.; Karagouni, A.D. Greek indigenous Streptomycetes as biocontrol agents against the soil-borne fungal plant pathogen $R$ hizoctoniasolani. J. Appl. Microbiol. 2013, 114, 1468-1479. [CrossRef] [PubMed]

13. Hayakawa, M. Studies on the isolation and distribution of rare actinomycetes in soil. Actinomycetologica 2008, 22, 12-19. [CrossRef]

14. Mincer, T.J.; Jensen, P.R.; Kauffman, C.A.; Fenical, W. Widespread and persistent populations of a major new marine actinomycete taxon in ocean sediments. Appl. Environ. Microbiol. 2002, 68, 5005-5011. [CrossRef] [PubMed]

15. Mauch, F.; Mauch-Mani, B.; Boller, T. Antifungal hydrolases in pea tissue: II. Inhibition of fungal growth by combinations of chitinase and $\beta$-1, 3-glucanase. Plant Physiol. 1988, 88, 936-942. [CrossRef] [PubMed]

16. Valli, S.; Suvathi, S.S.; Aysha, O.S.; Nirmala, P.; Vinoth, K.P.; Reena, A. Antimicrobial potential of Actinomycetes species isolated from marine environment. Asian Pac. J. Trop. Biomed. 2012, 2, 469-473. [CrossRef]

17. Ghaemy, M.; Aghakhani, B.; Taghavi, M.; Nasab, S.M.A.; Mohseni, M. Synthesis and characterization of new imidazole and fluorine-bisphenol based polyamides: Thermal, photophysical and antibacterial properties. React. Funct. Polym. 2013, 73, 555-563. [CrossRef]

18. Wilson, K. Preparation of genomic DNA from bacteria. In Current Protocols in Molecular Biology; Unit 2.4.1; Ausubel, F.M., Brent, R., Kingston, R.E., Moore, D.D., Smith, J.A., Seidman, J.G., Struhl, K., Eds.; John Wiley \& Sons: New York, NY, USA, 1987.

19. Lane, D.J. 16S/23S rRNA sequencing. In Nucleic Acid Techniques in Bacterial Systematics; Stackebrandt, E., Goodfellow, M., Eds.; John Wiley \& Sons: New York, NY, USA, 1991; pp. 115-148.

20. Nautiyal, C.S. An efficient microbiological growth medium for screening phosphate solubilizing microorganisms. FEMS Microbiol. Lett. 1999, 170, 265-270. [CrossRef]

21. Doumbou, C.L.; Salove, M.K.H.; Crawford, D.L.; Beaulieu, C. Actinomycetes, promising tools to control plant diseases and promote plant growth. Phytoprotection 2001, 82, 85-102. [CrossRef]

22. Schwyn, B.; Neilands, J.B. Universal chemical assay for the detection and determination of siderophores. Anal. Biochem. 1987, 160, 47-56. [CrossRef]

23. You, J.L.; Cao, L.X.; Liu, G.F.; Zhou, S.N.; Tan, H.M.; Lin, Y.C. Isolation and characterization of actinomycetes antagonistic to pathogenic Vibrio spp. from near shore marine sediments. World J. Microbiol. Biotechnol. 2004, 21, 679-682. [CrossRef]

24. Csaky, T. On the estimation of bound hydroxylamine. Acta Chem. Scand. 1984, 2, 450-454. [CrossRef]

25. Gordon, S.A.; Weber, R.P. Colorimetric estimation of indole acetic acid. Plant Physiol. 1951, 26, $192-195$. [CrossRef] [PubMed]

26. Skujins, J.J.; Potgieter, H.J.; Alexander, M. Dissolution of fungal cell walls by a streptomycetechitinase and beta-(1-3) glucanase. Arch. Biochem. Biophys. 1965, 111, 358-364. [CrossRef]

27. Bremner, J.M. Determination of nitrogen in soil by the Kjeldahl method. J. Agric. Sci. 1960, 55, 11-33. [CrossRef]

28. Walkley, A.; Black, I.A. An examination of Degtjareff method for determining soil organic matter and a proposed modification of the chromic acid titration method. Soil Sci. 1934, 37, 29-37. [CrossRef] 
29. Indananda, C.; Matsumoto, A.; Inahashi, Y.; Takahashi, Y.; Duangmal, K.; Thamchaipenet, A. Actinophytocolaoryzae gen. nov., sp. nov., isolated from root of Thai glutinous rice plants, a new member of the family Pseudonocardiaceae. Int. J. Syst. Evol. Microbiol. 2010, 60, 1141-1146. [CrossRef]

30. Verma, V.C.; Gond, S.K.; Kumar, A.; Mishra, A.; Kharwar, R.N.; Gange, A.C. EndophyticActinomycetes from Azadirachtaindica A. Juss.: Isolation, Diversity, and Anti-Microbial Activity. Microb. Ecol. 2009, 57, 749-756. [CrossRef]

31. Al-Dhabi, N.A.; Esmail, G.A.; Duraipandiyan, V.; Arasu, M.V. Chemical profiling of Streptomyces sp. Al-Dhabi-2 recovered from an extreme environment in Saudi Arabia as a novel drug source for medical and industrial applications. Saudi. J. Biol. Sci. 2019, 26, 758-766. [CrossRef]

32. Al-Dhabi, N.A.; Ghilan, A.K.M.; Esmail, G.A.; Arasu, M.V.; Duraipandiyan, V.; Ponmurugan, K. Bioactivity assessment of the Saudi Arabian Marine Streptomyces sp. Al-Dhabi-90, metabolic profiling and its in vitro inhibitory property against multidrug resistant and extended-spectrum beta-lactamase clinical bacterial pathogens. J. Inf. Pub. Health 2019, 549-556. [CrossRef]

33. Kaur, T.; Vasudev, A.; Sohal, S.K.; Manhas, R.K. Insecticidal and growth inhibitory potential of Streptomyces hydrogenans DH16 on major pest of India, Spodopteralitura (Fab.) (Lepidoptera: Noctuidae). BMC Microbiol. 2014, 14, 227. [CrossRef]

34. Verma, V.C.; Singh, S.K.; Prakash, S. Bio-control and plant growth promotion potential of siderophore producing endophytic Streptomyces from Azadirachtaindica A. Juss. J. Basic Microbiol. 2012, 51, 550-556. [CrossRef] [PubMed]

35. Hamdali, H.; Hafidi, M.; Virolle, M.J.; Ouhdouch, Y. Growth promotion and protection against damping-off of wheat by two rock phosphate solubilizing actinobacteria in a P-deficient soil under greenhouse conditions. Appl. Soil Ecol. 2008, 40, 510-517. [CrossRef]

36. Chen, Y.P.; Rekha, P.D.; Arun, A.B.; Shen, F.T.; Lai, W.A.; Young, C.C. Phosphate solubilizing bacteria from subtropical soil and their tricalcium phosphate solubilizing abilities. Appl. Soil Ecol. 2006, 34, 33-41. [CrossRef]

37. Tan, H.M.; Cao, L.X.; He, Z.F.; Su, G.J.; Lin, B.; Zhou, S.N. Isolation of endophyticactinobacteria from different cultivars of tomato and their activities against Ralstoniasolanaceraum In Vitro. World J. Microbiol. Biotechnol. 2006, 22, 1275-1280. [CrossRef]

38. Nimnoi, P.; Pongsilp, N.; Lumyong, S. Endophyticactinomycetes isolated from Aquilariacrassna Pierre ex Lec and screening of plant growth promoter's production. World J. Microbiol. Biotechnol. 2010, 26, 193-203. [CrossRef]

39. Khamna, S.; Yokota, A.; Lumyong, S. Actinobacteria isolated from medicinal plant rhizosphere soils: Diversity and screening of antifungal compounds, indole-3-acetic acid and siderophore production. World J. Microbiol. Biotechnol. 2009, 25, 649-655. [CrossRef]

40. Nimnoi, P.; Pongsilp, N. Genetic diversity and plant-growth promoting ability of the indole-3-acetic acid (IAA) synthetic bacteria isolated from agricultural soil as well as rhizosphere, rhizoplane and root tissue of Ficusreligiosa L., Leucaenaleucocephala and Piper sarmentosumRoxb. Res. J. Agric. Biol. Sci. 2009, 5, $29-41$.

41. Kumaran, S.; Deivasigamani, B.; Uttara, V. Chitinase Application—Review; Lambert Book Publishing House: Saarbrücken, Germany, 2012; ISBN 978-3-8484-4920-0.

42. Gopinath, L.R.; Christy, P.M.; Mahesh, K.; Bhuvaneshwari, R.; Divya, D. Identification and evaluation of effective bacterial consortium for efficient biogas production. J. Environ. Sci. Toxic. Food Technol. 2014, 8, $80-86$.

43. Karnchanawong, S.; Nissaikla, S. Effects of microbial inoculation on composting of household organic waste using passive aeration bin. Int. J. Recycl. Org. Waste Agric. 2014, 3, 113-119. [CrossRef]

44. Limaye, L.; Patil, R.; Ranadive, P.; Kamath, G. Application of potent actinomycete strains for bio-degradation of domestic agro-waste by composting and treatment of pulp-paper mill effluent. Adv. Microbiol. 2017, 7, 94-108. [CrossRef]

45. Tanaka, Y.; Murata, A.; Hayashida, S. Accelerated composting of cereal shochu-distillery wastes by actinomycetes: Promotive composting of shochudistillery wastes (I). Seibutsu-KogakuKaishi 1995, 73, 365-372.

46. Tandon, G. Bioproducts from residual lignocellulosic biomass. Advances in Biotechnology; Nawani, N.N., Khetmalas, M., Razdan, P.N., Pandey, A., Eds.; I.K. Internal Publishing House Pvt. Ltd.: New Delhi, India, 2015; pp. 52-75. 
47. Figueiredo, M.D.; Seldin, L.; de Araujo, F.F.; Mariano, R.D. Plant growth promoting rhizobacteria: Fundamentals and applications. In Plant Growth and Health Promoting Bacteria; Springer: Berlin/Heidelberg, Germany, 2010; pp. 21-43.

48. Lamsal, K.; Kim, S.W.; Kim, Y.S.; Lee, Y.S. Biocontrol of late blight and plant growth promotion in tomato using rhizobacterial isolates. J. Microbiol. Biotechnol. 2013, 23, 897-904. [CrossRef] [PubMed]

49. Qiao, J.Q.; Wu, H.J.; Huo, R.; Gao, X.W.; Borriss, R. Stimulation of plant growth and biocontrol by Bacillus amyloliquefaciens subsp. plantarum FZB42 engineered for improved action. Chem. Biol. Technol. Agric. 2014, 1, 12. [CrossRef]

(C) 2019 by the authors. Licensee MDPI, Basel, Switzerland. This article is an open access article distributed under the terms and conditions of the Creative Commons Attribution (CC BY) license (http://creativecommons.org/licenses/by/4.0/). 